\title{
Bioactive Coatings on Porous Titanium for Biomedical Applications
}

\author{
C. Domínguez-Trujillo ${ }^{1}$, F. Ternero ${ }^{1}$, J.A. Rodríguez-Ortiz ${ }^{1}$, S. Heise ${ }^{2}$, A.R. Boccaccini ${ }^{2}$, J. \\ Lebrato $^{3}$ and Y. Torres ${ }^{1 *}$
}

${ }^{1}$ Department of Engineering and Materials Science and Transportation, University of Seville, Seville, Spain

${ }^{2}$ Friedrich-Alexander-University Erlangen-Nuremberg, Institute of Biomaterials - Erlangen, Germany

${ }^{3}$ Grupo TAR, Escuela Politécnica Superior, Universidad de Sevilla, Sevilla, España

\begin{abstract}
Commercial pure titanium is a recognized and accepted material for cortical bone tissue substitution. However, stress-shielding phenomena and lack of osseointegration result in significant limitations. This work is focused on the achievement of an effective solution for both problems via fabrication of porous titanium substrates coated with bioactive glass. Substrates were obtained through the space holder technique giving values of stiffness and yield strength compatible with cortical bone tissue to reduce the stress-shielding phenomenon. Titanium substrates were coated with different number of layers of bioactive glass 45S5 by dripping sedimentation. The substrates porosity was characterized by different techniques. Ultrasound, compression and micro-mechanical testing were used for mechanical properties evaluation. After substrates coating, the infiltration ability, coating homogeneity and structural integrity (chipping and cracking) were evaluated for each coating layer. The chemical composition of coating and phases were studied before and after in vitro tests in Simulated Body Fluid. The results showed more homogenous coating, adherence and greater hydroxyapatite growth for the tri-layer system in both dense and porous samples. Besides, the relation of $\mathrm{Ca} / \mathrm{P}$ was closed to that of stoichiometric hydroxyapatite in the human body. The coated porous titanium could be potentially used in load bearing partial implants with improved osseointegration.
\end{abstract}


Keywords: Porous titanium, stress-shielding, osseointegration, bioactive glass coating, hydroxyapatite, in vitro bioactivity.

\section{Introduction}

Diseases and aging influence the bone tissue quality, making a total or partial bone replacement by implants or prosthesis necessary. The implant functionality is affected by several factors: intrinsic properties of materials and components (shape and geometry features); host bone tissue (quality and quantity); and topography, biochemistry and surface energy of the biointerface between the bone and the implant [1]. Additionally, other factors related to the environmental stimulation also affect prostheses behavior, e.g mechanical stimulation (local and remote), the systemic immunological response (natural and modulated), and / or some medicine, drugs and systemic effects [1]. The biointerfacial properties are the main elements for the correct performance of the system. The goal of implant design is to reach a biofunctional (bone in-growth and osseointegration) and biomechanical (stiffness and yield strength) equilibrium [2]. Although commercial pure titanium (c.p. Ti) and its alloys are commonly used as bone implants [3], they exhibit some unsolved issues: stress shielding phenomenon and lack of osseointegration [2,4]. The reduction of the implant Young's modulus can be addressed by fabricating porous materials [5-9]. Regarding the improvement of osseointegration, implant surface modifications have been widely performed [2], [4-8] by implementing a variety of techniques that involve physical and chemical changes, e.g. controlling the surface roughness or obtaining bioactive surfaces [10].

The success of implants depends on material properties including mechanical behavior, microstructure and surface characteristics [11]. The surface plays an important role in the response of artificial devices in a biological environment making surface modification one of the most common approaches to improve the biocompatibility. Among bioceramics, hydroxyapatite $\left[\mathrm{Ca}_{10}\left(\mathrm{PO}_{4}\right)_{6}(\mathrm{OH})_{2}\right]$ (HA) is known for its biocompatibility because of its similar chemical crystallographic structure to the mineral phase of living bone [12]. Hydroxyapatite is an 
osteoinductive, nontoxic, non-immunogenic agent and has the ability to form strong chemical bonds with natural bone $[13,14]$. According to its chemical formula, HA has a $\mathrm{Ca} / \mathrm{P}$ molar ratio of 1.67 (5:3) which is close to the $\mathrm{Ca} / \mathrm{P}$ ratio in bone minerals (between 1.37 and 1.87). [15]

Bioactive glasses (BGs) are being increasingly investigated as promising scaffold materials for bone regeneration since the discovery of 45S5 BG by Larry Hench in 1969 [13]. BGs have a wellrecognized superior osteoconductivity, controlled biodegradability, the capability of activating osteogenic gene expression, angiogenic potential 0 [16], they promote the formation of bone mineral-like phases (including HA) and have drug delivery abilities [14,17]. Bioactive glasses exhibit high bioactivity through the release of dissolution ions such as $\mathrm{Ca}, \mathrm{P}$ and $\mathrm{Si}$, which may also affect gene expression in osteogenic cells and bone vascularisation, and could lead to the subsequent promotion of a high rate of bone formation [16]. A. Scislowska-Czarnecka et al. [18] tested the effect on macrophage activation after coating porous titanium substrates with BG by sol-gel technique, and compared it to different ceramic coatings. It was found that more cells were adhered to BG-Ti system than to other combinations, as well as to Ti substrate with no covering. The BG coating on porous titanium showed also good biocompatibility, not stimulating macrophages to an inflammatory response.

The use of bioactive glasses is limited for load-bearing applications due to their brittleness. There are two processing methods to fabricate a glass: traditional melt-quenching (commercial bioactive glasses) and the sol-gel route (assembled nanoparticles - intrinsic nanoporosity). The implementation of most of the techniques for glass fabrication requires the control of a high number of parameters and a high cost. In terms of types, the main glasses are conventional silicate (similar to Bioglass ${ }^{\circledR} 45 \mathrm{~S} 5$ ), phosphate-based and borate-based glasses. The interest of borate-based and phosphate-based glasses in soft tissue response is related to their fast dissolution compared to silicate-based glasses [19]. Nevertheless, BonAlive ${ }^{\circledR}$ (S53P4) has been highlighted in many clinical 
trials. In this context, although there are more available data for S53P4 than for 45S5, the degradation rate of S53P4 in the human body is lower [19]. In addition, 45S5 and S53P4 cannot be produced as amorphous bioactive glass scaffolds due to their crystallization during the sintering. For this reason, they are mostly employed as bioactive coatings on inert metallic substrates. In terms of fabrication, the temperatures should be chosen carefully in order to avoid glass crystallization and substrate degradation [20].

Fully dense commercial pure Ti substrates coated with BG (bioactive glass 45S5) have been widely investigated [21]. However there has been only limited work focusing on BG coatings onto porous titanium substrates [22].The aim of this work is the fabrication of porous titanium substrates coated with BG by implementing a simple, repetitive and economical deposition technique, consisting on sedimentation by dripping. The materials combination offers a potential biomechanical (stiffness and yield strength) and biofunctional (ingrowth and osseointegration) equilibrium, recommended for partial cortical bone tissue substitution.

\section{Conclusions}

The study of the porous titanium substrates coated with 45S5 bioactive glass allows to conclude the following:

1- A novel sedimentation technique was introduced to coat Ti substrates with 45S5 BG powder. The parameters to control are BG particle size, concentration, number of coating layers and thermal treatment. Using porous titanium substrates, combined with dripping sedimentation, involves the possibility of an economically and commercially viable alternative to obtain BG coatings for implants and scaffolds.

2- The coated porous substrate has a better adherence than that of full dense titanium. This can be attributed to the roughness of the pore walls and the anchoring associated with the infiltration of BG particles into the pores. The size and content of the pores of the titanium substrates studied in 
this work as well as the mechanical properties (E and yield strength) meet the requirements of the cortical bone. However, fatigue behavior (static and cyclic) and the presence of corrosion phenomena should also be considered.

3- To obtain a homogeneous BG coating three layers were required (more layers compromises the integrity and adhesion of the coating). Nevertheless, it is important to control the rates, temperature and atmosphere of the thermal treatment in terms of BG crystallization and micromechanical properties of the coating (presence of micro-porosity, as well as quality of union between the BG particles and the coating/substrate interface).

4- The results suggests better osseointegration employing three BG coating layers on the substrates, due to greater formation of HA in contact with SBF. Nevertheless, the compromise between the thermal expansion coefficient (coating adherence to the substrate) and the bioactivity must be considered to choose the bioactive glass.

\section{Acknowledgements}

The authors dedicate this paper to the memory of Prof. Juan José Pavón Palacio (University of Antioquia, Colombia). This work was supported by the Ministry of Economy and Competitiveness of the State General Administration of Spain under the grant MAT2015-71284-P. The authors would like to thank technician J. Pinto for the assistance in mechanical characterization.

\section{Data availability}

The raw/processed data required to reproduce these findings cannot be shared at this time as the data also forms part of an ongoing study. 


\section{References}

[1] J.P. Allain, M. Echeverry, J. Pavón, S. Arias; Nanostructured Biointerfaces in: K. Iniewski, S.Selimovic (Eds.),. Nanostructured Biointerfaces, CRC Press, 2014, 42-67.

[2] L. L. Hench, J.R Jones, Biomaterials, Artificial Organs and Tissue Engineering, Woodhead Pub. Ltd., Cambridge, England, 2005.

[3] J. D. Enderle, J. D. Bronzino, Introduction to biomedical engineering, third ed., Elsevier Ltd, Academic Press, Amsterdam, Boston:, 2012.

[4] A. Stamboulis, A. Boccaccini, L. Hench, Novel Biodegradable Polymer/Bioactive Glass Composites for Tissue Engineering Applications, Adv. Eng. Mater., 24 (2002) 105-109.

[5] S. Borjas, E.J. Gil, L. Cordero, J.J. Pavón, J.A. Rodriguez-Ortiz, A.R. Boccaccini, Y. Torres, Electrophoretic Deposition and Characterization of Chitosan/45S5 Bioactive Glass Composite Coatings on Porous Titanium for Biomedical Applications, Key Engineering Materials, 654 (2015) 189-194.

[6] Y. Torres, J. J. Pavón, J. A. Rodríguez, Processing and characterization of porous titanium for implants by using $\mathrm{NaCl}$ as space holder, J. Mater. Process. Technol., 212 (2012) 10611069.

[7] J. Jia, A. R. Siddiq, A. R. Kennedy, Porous titanium manufactured by a novel powder tapping method using spherical salt bead space holders: Characterisation and mechanical properties., J. Mech. Behav. Biomed. Mater., 48 (2015) 229-40.

[8] Y. Torres, J. A. Rodríguez, S. Arias, M. Echeverry, S. Robledo, V. Amigo, J. J. Pavón, Processing, characterization and biological testing of porous titanium obtained by spaceholder technique, J. Mater. Sci., 47 (2012) 6565-6576.

[9] L. L. Hench, Biomaterials: A forecast for the future, Biomaterials, 19 (1998) 1419-1423.

[10] L. L. Hench, The story of Bioglass, J. Mater. Sci. Med., 17 (2006) 967-978.

[11] T. Albrektsson, P.I. Brånemark, H.A. Hansson, J. Lindström, Osseointegrated titanium implants. Requirements for ensuring a long-lasting, direct bone-to-implant anchorage in man, Acta Orthop Scand., 52 (1981) 155-170.

[12] T. Kokubo, H. Kim, M. Kawashita, T. Nakamura, REVIEW Bioactive metals: preparation and properties, Journal of Materials Scienc, 15 (2004) 99-107. 
[13] Hench, L.L., Best, S.M., 2004. Ceramics, glasses and glass-ceramics. In: Ratner, B.D., Schoen, F.J., Hoffman, A.S., Lemons, J.E. (Eds.), Biomaterials Science: An Introduction to Materials in Medicine. Elsevier Academic Press, Oxford, pp. 153-170.

[14] K. Jurczyk, K. Niespodziana, M.U. Jurczyk, M. Jurczyk,. Synhesis and characterization of titanium-45S5 Bioglass nanocomposites, Mater. Des., 32 (2011) 2554-2560.

[15] S. Wu, X. Liu, K.W.K. Yeung, C. Liu, X. Yang, Biomimetic porous scaffolds for bone tissue engineering, Materials Science and Engineering R, 80 (2014) 1-36.

[16] A.A. Gorustovich, T. Steimetz, R.L. Cabrini, J.M. Porto López., Osteoconductivity of strontium-doped bioactive glass particles: a histomorphometric study in rats, J Biomed Mater Res A., 92 (2010) 32-37.

[17] A. Hoppe, N.S. Guldal, A.R. Boccaccini, A review of the biological response to ionic dissolution products from bioactive glasses and glass-ceramics, Biomaterials, 32 (2011) $2757-2774$.

[18] A. Scislowska-Czarnecka, E. Menaszek, B. Szaraniec, E. Kolaczkowska, Ceramic modifications of porous titanium: Effects on macrophage activation, Tissue and Cell, 44 (2012) 391-400.

[19] J.R. Jones, Reprint of: Review of bioactive glass: From Hench to hybrids, Acta Biomaterialia, 23 (2015) 53-82.

[20] C.Y. Tang, C.P. Tsui, D.J. Janackovic, P.S. Uskokovic, Nanomechanical properties evaluation of bioactive glass coatings on titanium alloy substrate, J. Optoelectron. Adv. Mater., 8 (2006) 1194-1199.

[21] H. Farnoush, F. Muhaffelb,H. Cimenoglu, Fabrication and characterization of nano-HA-45S5 bioglass compositecoatings on calcium-phosphate containing micro-arc oxidized CPTisubstrates, Applied Surface Science, 324 (2015) 765-774.

[22] C.Domínguez-Trujillo, F. Ternero, J.A.Rodríguez-Ortiz, J.J.Pavón, I. MontealegreMeléndez, C.Arévalo, F. García-Moreno, Y.Torres, Improvement of the balance between a reduced stress shielding and bone ingrowth by bioactive coatings onto porous titanium substrates, Surface \& coatings technology, 338 (2018) 32-37.

[23] ASTM F67-13, Standard Specification for Unalloyed Titanium, for Surgical Implant Applications (UNS R50250, UNS R50400, UNS R50550, UNS R50700), ASTM International (2013). 
[24] S. Munoz, J.J. Pavon, J.A. Rodriguez-Ortiz, A. Civantos, J.P. Allain, Y. Torres, On the influence of space holder in the development of porous titanium implants: Mechanical, computational and biological evaluation, Materials characterization, 108 (2015) 68-78.

[25] ASM-International. Nondestructive evaluation and quality control. 9th ed. (1989).

[26] J. Müller-Rochholz, Determination of the elastic properties of lightweight aggregate by ultrasonic pulse velocity measurement, Int. J. Cem. Compos. Light. Concr., 1 (1979) 87-90.

[27] Y. Torres, J.J. Pavón, I. Nieto, J.A. Rodriguez, . Conventional Powder Metallurgy Process and Characterization of Porous Titanium for Biomedical Applications, Metallurgical and Materials Transactions B-Process Metallurgy and Materials Processing Science, 42 (2011) 891-900.

[28] Y. Torres, S. Lascano, J.Bris, J.J. Pavón, J.A. Rodriguez,Development of porous titanium for biomedical applications: A comparison between loose sintering and space-holder techniques, Materials science \& engineering c-materials for biological applications, 37 (2014) 148-155.

[29] ASTM B962-15, Standard Test Methods for Density of Compacted or Sintered Powder Metallurgy (PM) Products Using Archimedes’ Principle, ASTM International (2015).

[30] ASTM E9-09, Standard Test Methods of Compression Testing of Metallic Materials at Room Temperature, ASTM International (2009).

[31] S. Foppiano, S.J. Marshall, G.W. Marshall, E.Saiz, A.P. Tomsia, Bioactive glass coatings affect the behavior of osteoblast-like cells, Acta Biomaterialia, 3 (2007) 765-771.

[32] S. Lopez-Esteban, E. Saiz, S. Fujino, T. O ku, K. Suganuma, A.P. Tomsia, Bioactive glass coatings for orthopedic metallic implants, Journal of the European Ceramic Society, 23 (2003) 2921-2930.

[33] W.C. Oliver, G.M. Pharr, An improved technique for determining hardness and elastic modulus using load and displacement sensing indentation experiments, J. Mater. Res., 7 (1992) 1564-1583.

[34] M. Mata, J. Alcalá, The role of friction on sharp indentation, J. Mech. Phys. Solids., 52 (2004) 145-165.

[35] W.C. Oliver, G.M. Pharr, Measurement of hardness and elastic modulus by instrumented indentation: Advances in understanding and refinements to methodology, J. Mater. Res. 19 (2004) 3-20. 
[36] M.R. VanLandingham, Review of Instrumented Indentation, J. Res. Natl. Inst. Stand. Technol., 108 (2003) 249-265.

[37] Ö.H. Andersson, G. Liu, K.H.Karlsson, L. Niem, J. Miettine, J. Juhanoja, In vivo behaviour of glasses in the $\mathrm{SiO} 2-\mathrm{Na} 2 \mathrm{O}-\mathrm{CaO}-\mathrm{P} 2 \mathrm{O} 5-\mathrm{Al} 2 \mathrm{O} 3-\mathrm{B} 2 \mathrm{O} 3$ system, J Mater Sci MaterMed, 1 (1990) 219-227.

[38] T. Kokubo, H. Takadama, How useful is SBF in predicting in vivo bone bioactivity, Biomaterials, 27 (2006) 2907-2915.

[39] J. Currey, Handbook of Biomaterials Properties, J. Black, H. Garth (eds.), Springer - Verlag, London 1998.

[40] D.C. Clupper, L.L. Hench, Crystallization kinetics of tape cast bioactive glass 45S5, J NonCrys Solid, 318 (2003) 43-48.

[41] Q.Z. Chen, I.D. Thompson, A.R. Boccaccini, 45S5 Bioglass ${ }^{\circledR}$-derived glass-ceramic scaffolds for bone tissue engineering, Biomaterials, 27 (2006) 2414-2425.

[42] D.C. Clupper, Jr. J.J. Mecholsky, G.P. La Torre, D.C. Greenspan, Sintering temperature effects on the in vitro bioactive response of tape cast and sintered bioactive glass-ceramic in Tris buffer, J. Biomed. Mater. Res., 57 (2001) 532-40.

[43] D.C.. Clupper, Jr. J.J. Mecholsky, G.P. LaTorre, D.C. Greenspan, Bioactivity of tape cast and sintered bioactive glass-ceramic in simulated body fluid, Biomaterials 23 (2002) 2599-606.

[44] P. Sarria, Y. Torres, F. J. Gotor, E. Gutiérrez, M. Rodríguez, R. González, L. Hernández, E. Peon, H. Guerra, J. E. González, Processing and characterization of Ti-6Al-4V samples manufactured by selective laser melting, Key Engineering Materials, 704 (2016) 260-268.

[45] S. Ferraris, A. Venturello, M. Miola, A. Cochis, L. Rimondini, S. Spriano, Antibacterial and bioactive nanostructured titanium surfaces for bone integration, Appl. Surf. Sci., 311 (2014) 279-291.

[46] G. Ciobanu, O. Ciobanu, Investigation of the effect of collagen and vitamins on biomimetic hydroxyapatite coating formation on titanium surfaces, Mater. Sci. Eng. C., 33 (2013) 16831688.

[47] M.R. Azenha, O. Peitl, V.M. Barros, Bone response to biosilicateswith different crystal phases, Braz. Dent. J., 21 (2010) 383-389.

[48] Z. Mladenović, A. Johansson, B. Willman, K. Shahabi, E. Björn, M. Ransjö, Soluble silica inhibits osteoclast formation and bone resorption in vitro, Acta Biomaterialia, 10 (2014) 406418. 
[49] R.J. Friederichs, R.A. Brooks, M. Ueda, S.M. Best, In vitro osteoclast formation and resorption of silicon-substituted hydroxyapatite ceramics, J. Biomed. Mater. Res. Part A, 103 (2015) 3312-3322. 
Table 1. Density and microstructural parameters of titanium substrates.

\begin{tabular}{|c|c|c|c|c|c|c|}
\hline \multirow{3}{*}{ Substrate } & \multicolumn{3}{|c|}{ Archimedes' Method } & \multicolumn{3}{|c|}{ Image Analysis } \\
\hline & \multirow{2}{*}{$\begin{array}{c}\rho \\
{\left[\mathrm{g} / \mathrm{cm}^{3}\right]}\end{array}$} & \multicolumn{2}{|c|}{ Porosity (\%) } & \multirow{2}{*}{$\begin{array}{c}\text { Total } \\
\text { Porosity } \\
(\%)\end{array}$} & \multirow{2}{*}{$\mathrm{D}_{\mathrm{eq}}(\mu \mathrm{m})$} & \multirow{2}{*}{$\mathrm{F}_{\mathrm{f}}$} \\
\hline & & Total & Interconnected & & & \\
\hline Fully Dense & 4.5 & $2.4 \pm 0.3$ & $0.4 \pm 0.2$ & $1.2 \pm 0.2$ & $5.5 \pm 0.2$ & $\sim 1$ \\
\hline Porous & $2.4 \pm 0.1$ & $47.0 \pm 1.0$ & $44.3 \pm 1.3$ & $51.8 \pm 1.3$ & $161 \pm 29$ & 0.7 \\
\hline
\end{tabular}


Table 2. Micro-indentation (P-h) parameters of the substrates and coating.

\begin{tabular}{|c|c|c|c|c|c|c|c|}
\hline \\
\hline & & & $A$ & $B$ & $C$ & $(B-A)$ & $(B-C) / B$ \\
\hline \multicolumn{3}{|c|}{ Bioactive glass } & 11.3 & 12.2 & 4.3 & 0.9 & 65.0 \\
\hline \multirow{3}{*}{$\begin{array}{c}\text { Fully } \\
\text { dense } \\
\text { substrate }\end{array}$} & \multirow{6}{*}{ 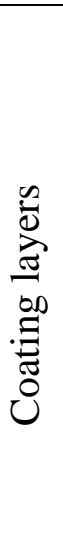 } & Without & 17.5 & 18.3 & 11.7 & 0.9 & 36.3 \\
\hline & & 1 & 15.0 & 16.2 & 8.1 & 1.2 & 50.3 \\
\hline & & 3 & 19.1 & 20.4 & 11.8 & 1.2 & 42.2 \\
\hline \multirow{3}{*}{$\begin{array}{l}\text { Porous } \\
\text { substrate }\end{array}$} & & Without & 21.7 & 23.1 & 10.3 & 1.4 & 55.5 \\
\hline & & 1 & 16.8 & 19.9 & 9.7 & 3.1 & 51.2 \\
\hline & & 3 & 27.4 & 30.0 & 18.6 & 2.5 & 38.0 \\
\hline
\end{tabular}




\section{Figure captions}

Figure 1. Experimental procedure: Fabrication and characterization of BG coated titanium substrates.

Figure 2. Particle size distribution of a) Titanium c.p., b) Ammonium bicarbonate, c) BG particles.

Figure 3. Macroscopic appearance of the coated titanium substrates before and after thermal treatment, influence of the number of coating layers (sample diameter: $12 \mathrm{~mm}$ ).

Figure 4. Confocal Images. Fully dense and porous substrate images for no coating (a), b)), one BG coating layer after thermal treatment (c), d)) and three BG coating layer after thermal treatment (e), f)).

Figure 5. Applied load $v s$ penetration depth curves for several substrate-coating systems investigated. The number of BG coating layers influences the P-h graphics for a) Fully dense and b) Porous samples.

Figure 6. Schematic view of the top and cross section of coated porous substrate and SEM images of the cross sectional view of coated fully dense and porous substrates. Inset: detailed view of the chipping of the coating in the fully dense substrate.

Figure 7. XRD patterns (left) and SEM images (right) for 45S5 BG particles and coated samples: A. 45S5 BG particles before sintering, B. 45S5 BG sintered sample. C. Porous cp-Ti substrate with one coating layer of 45S5 BG after 21 days in SBF and D. Porous cp-Ti substrate with three coating layers of 45S5 BG after 21 days in SBF.

Figure 8. a) XRD patterns and b) SEM micrographs of fully dense cp-Ti sample with three BG coating layers showing massive formation of HA after 21 days in SBF. 
Figure 9. ICP data of: a) porous cp-Ti with one coating layer of BG, b) porous cp-Ti with three coating layer of BG and c) full dense cp-Ti with three coating layer of BG after 21 days in SBF. EDX spectra of: d) porous cp-Ti with one coating layer of BG, e) porous cp-Ti with three coating layer of BG and f) full dense cp-Ti with three coating layer of BG after 21 days in SBF. 


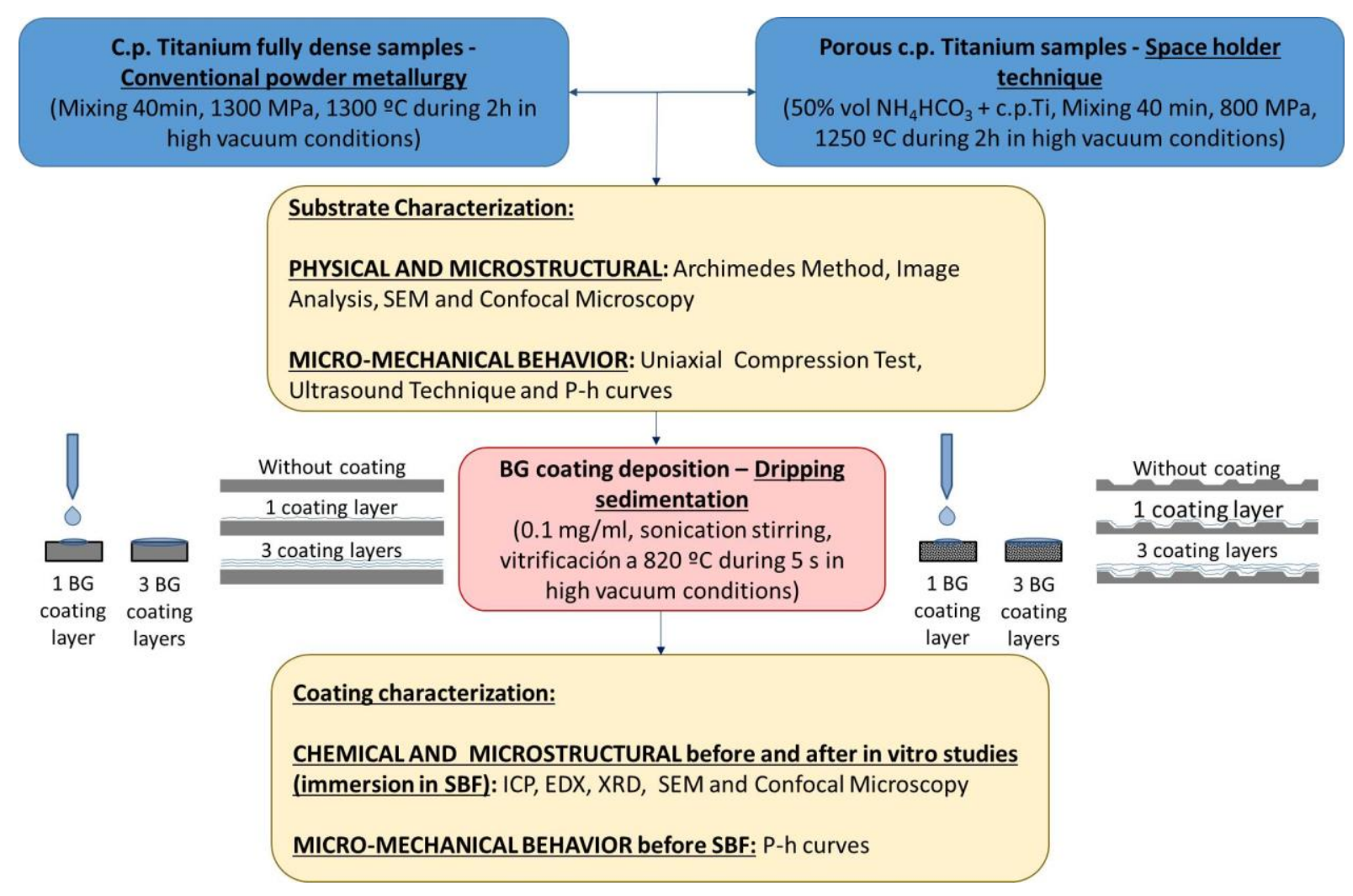

Figure 1.
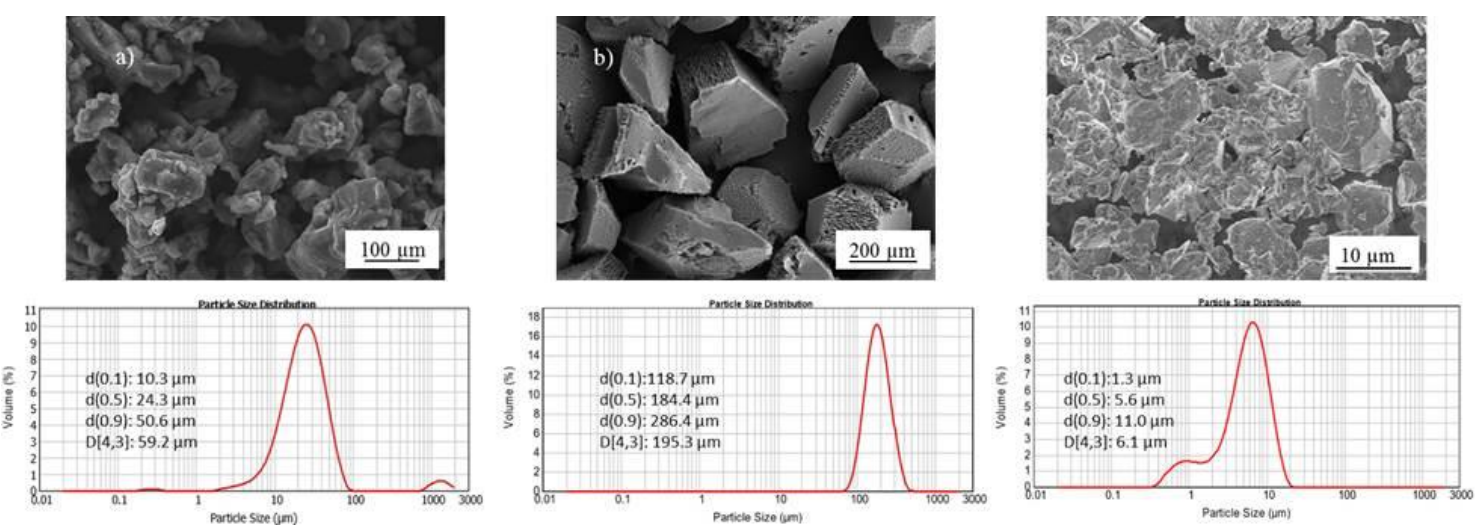

Figure 2. 


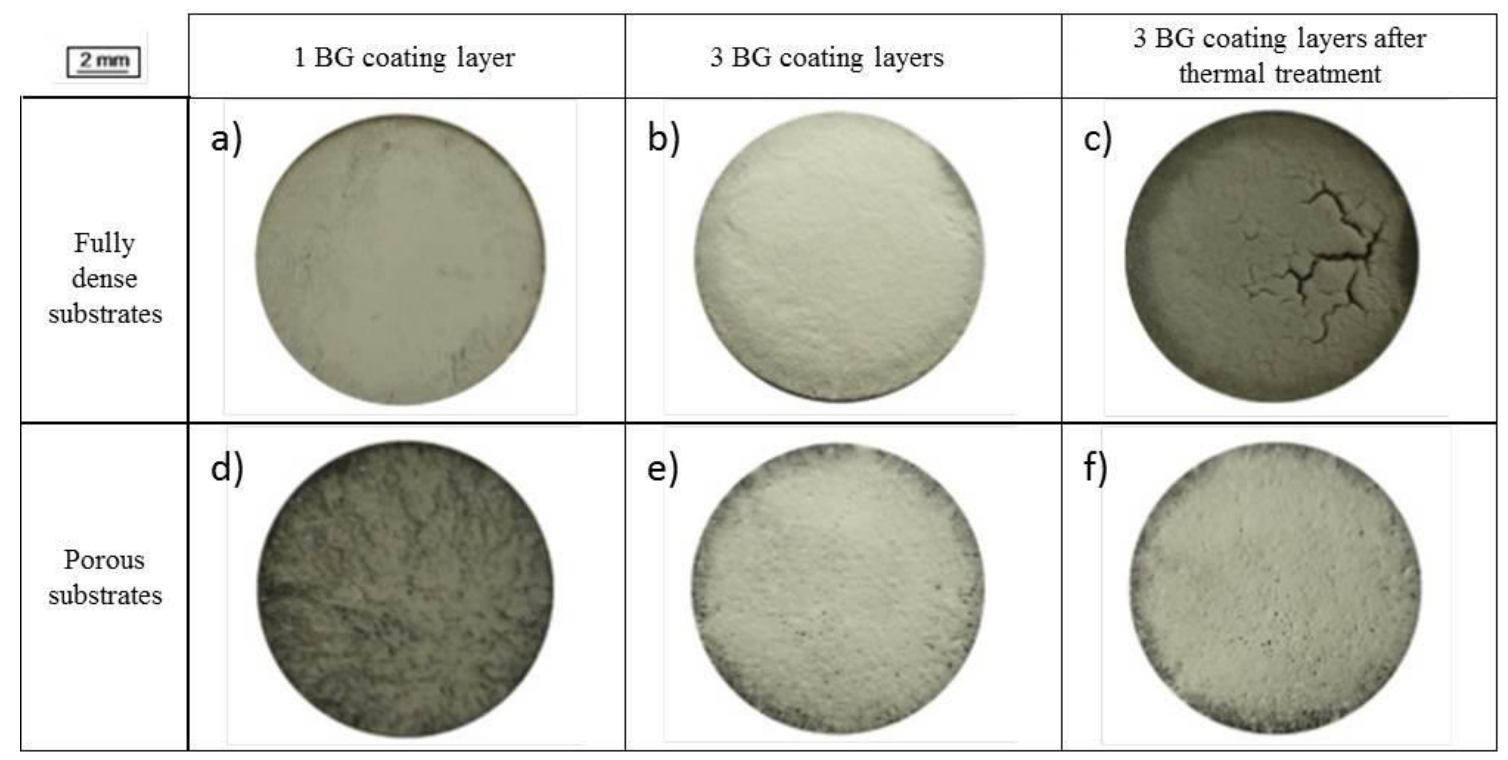

Figure 3. 


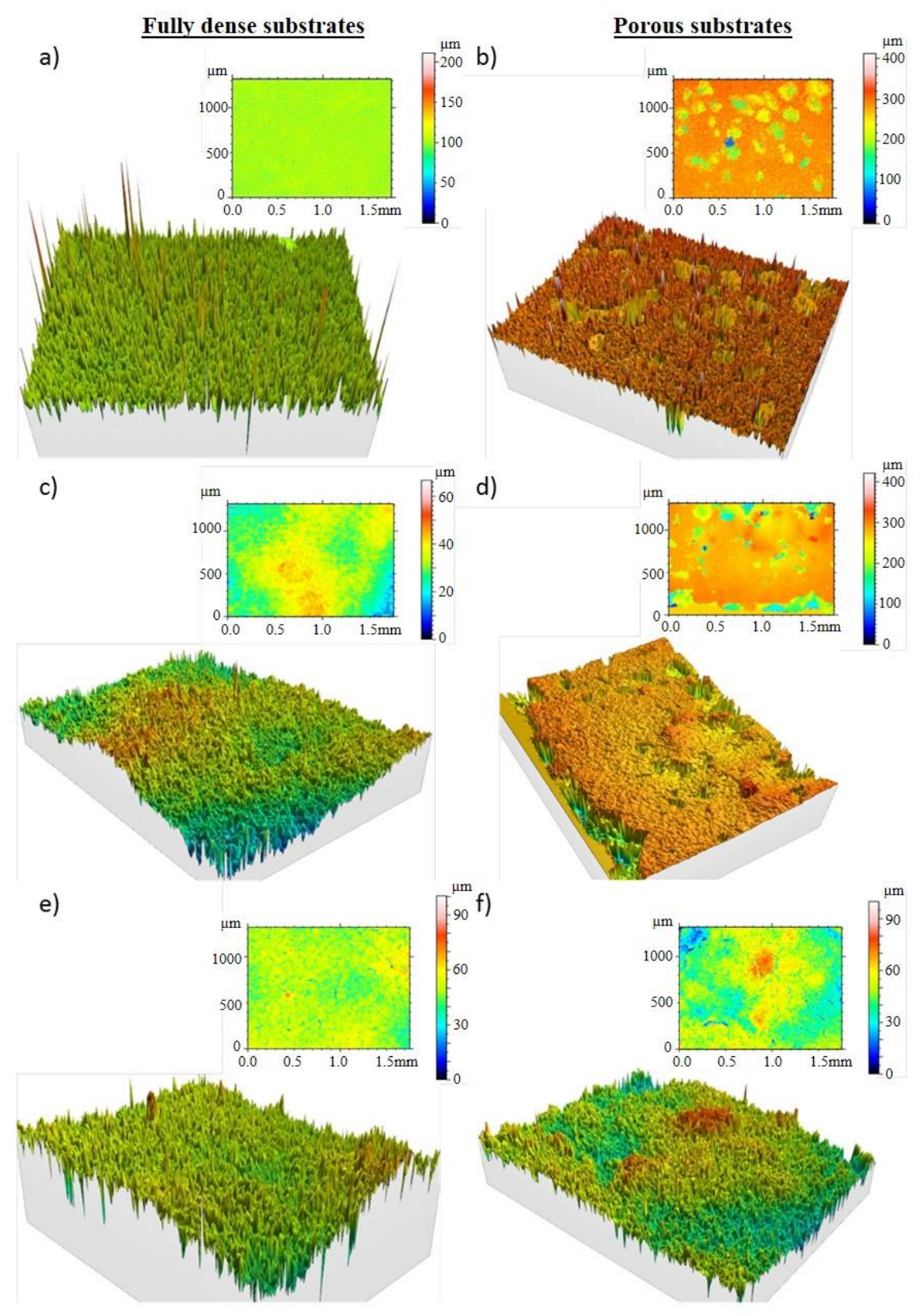

Figure 4. 


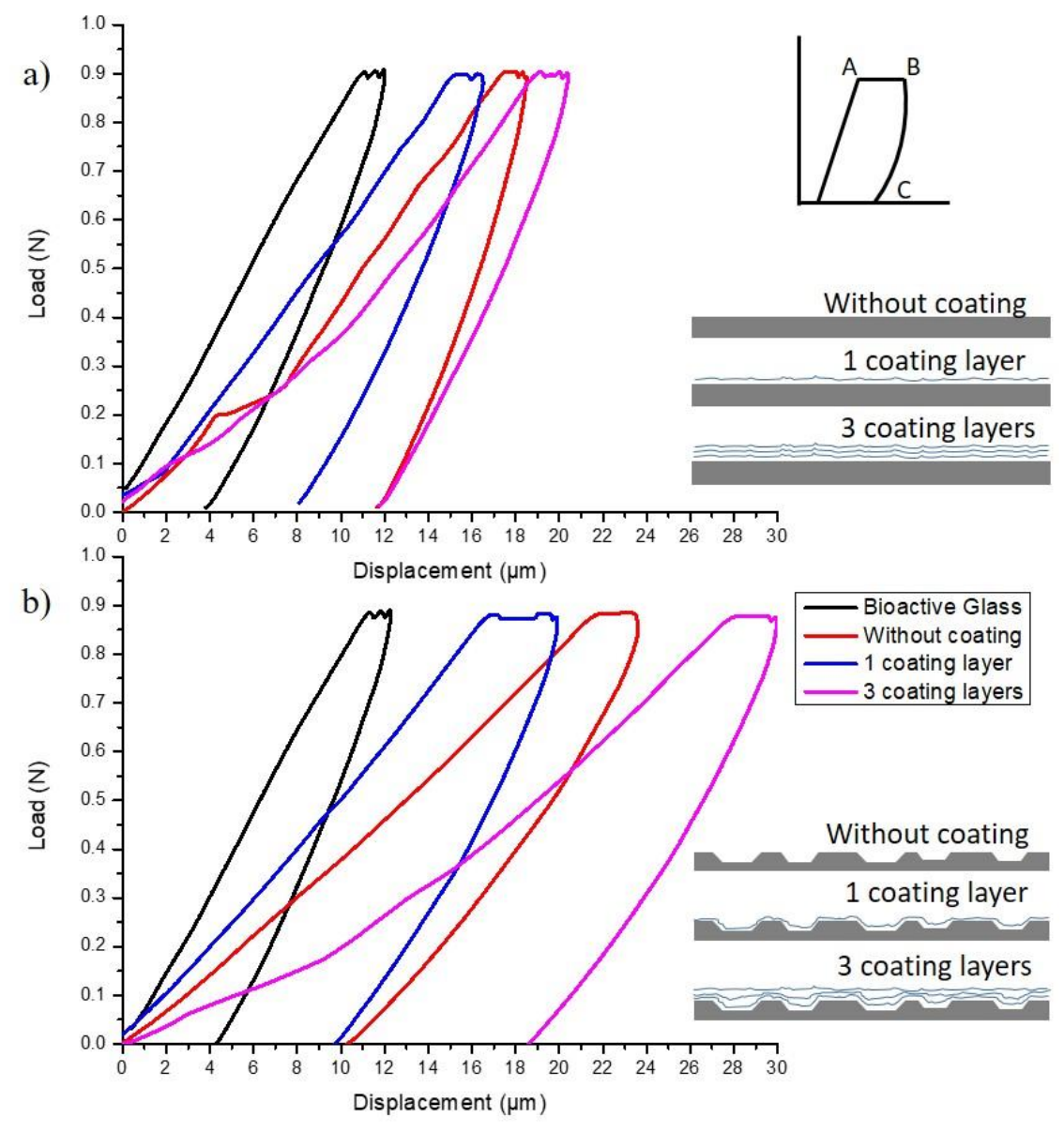

Figure 5.

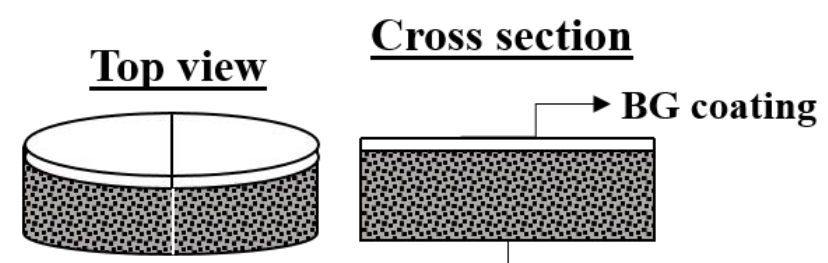

$\rightarrow$ Titanium substrate
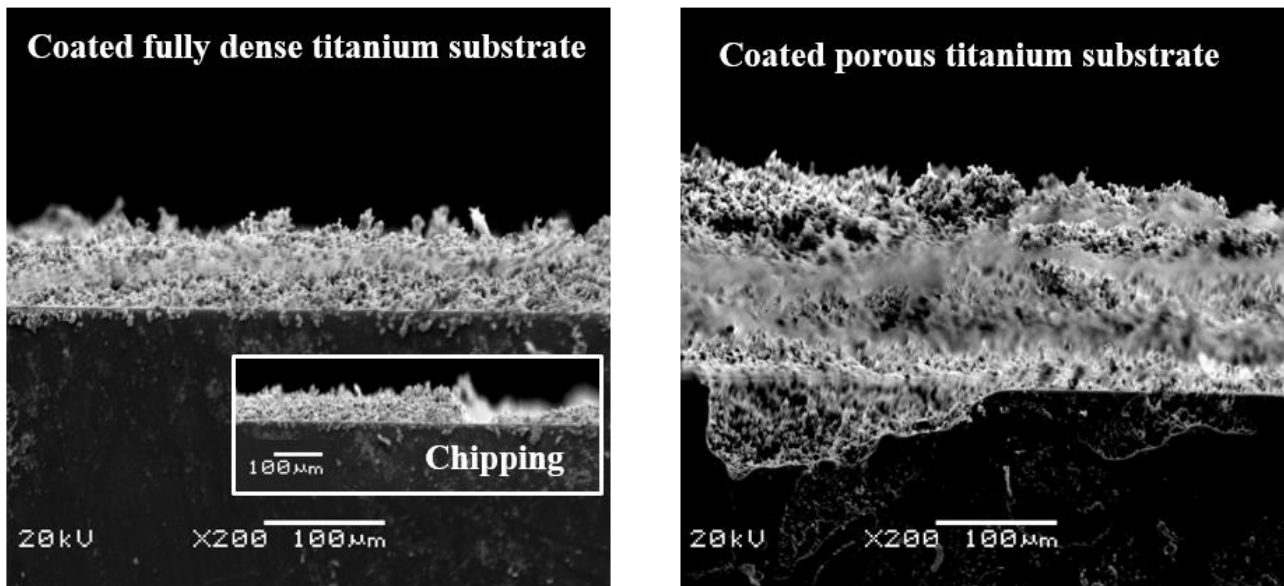

Figure 6. 

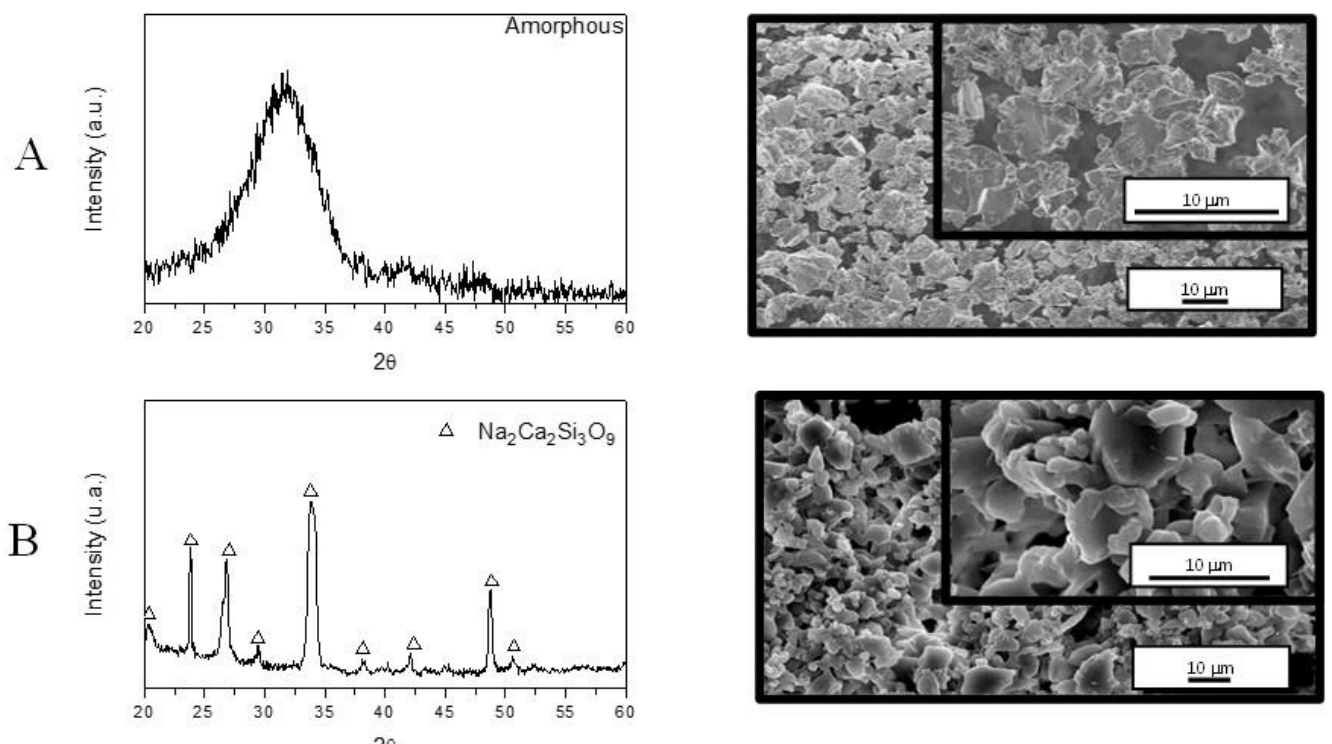

$\mathrm{C}$ \#
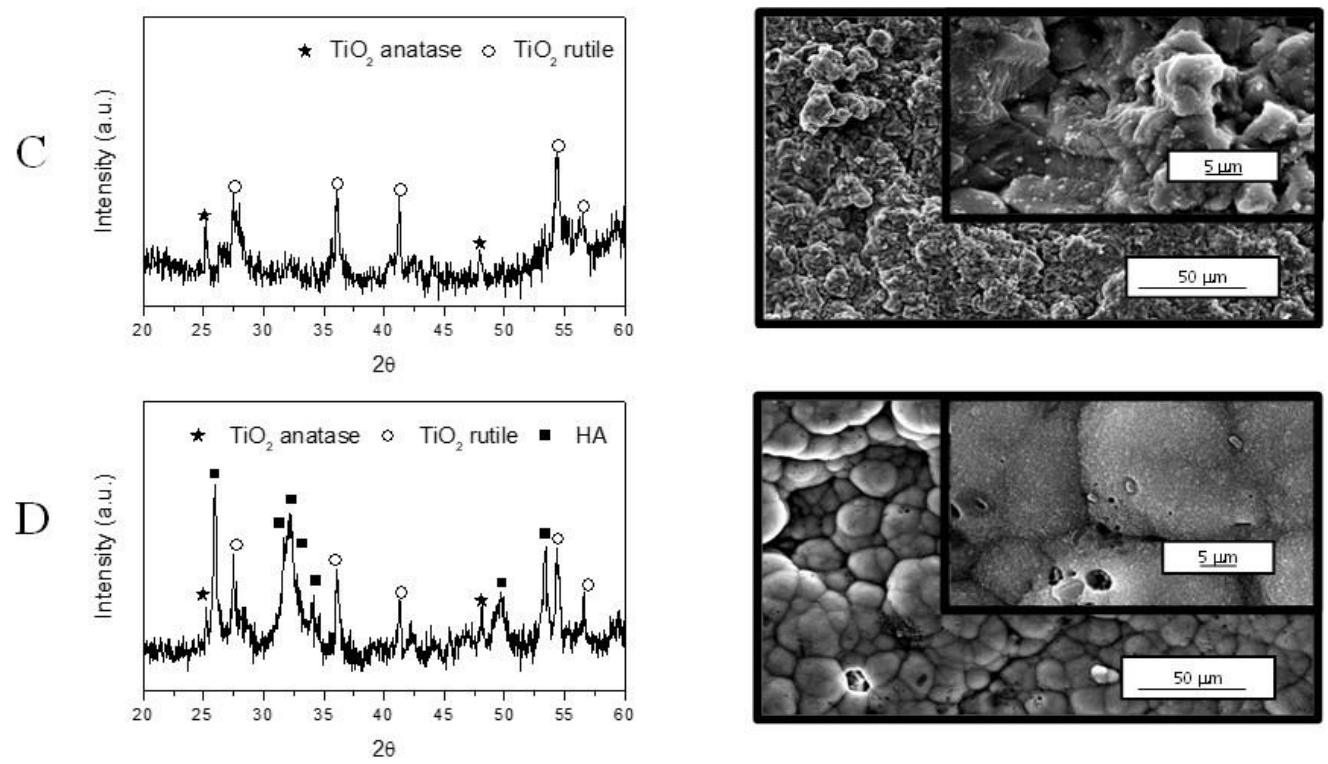

Figure 7. 

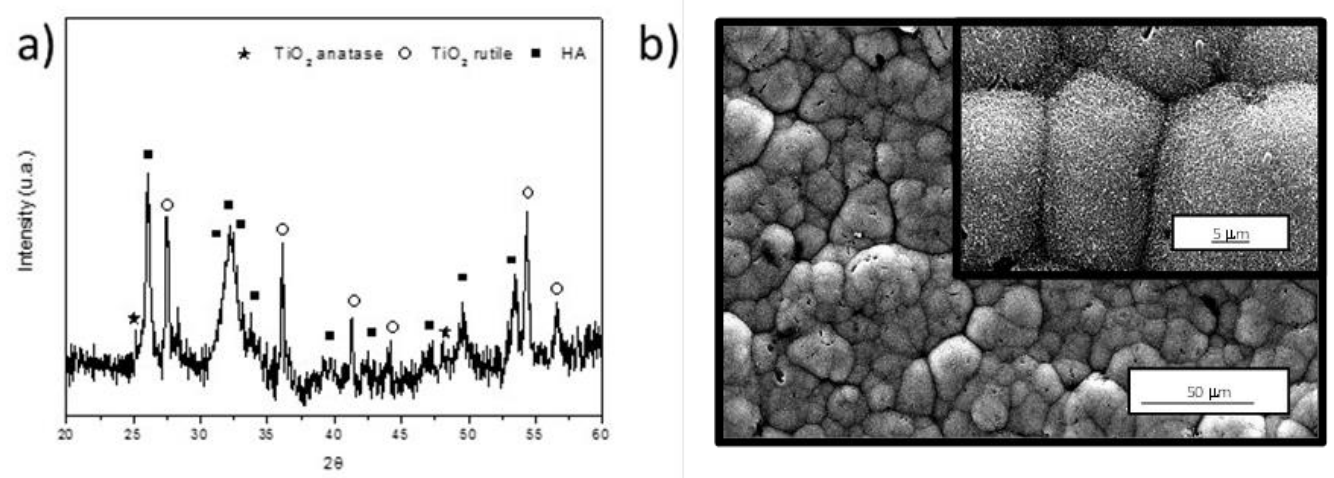

Figure 8

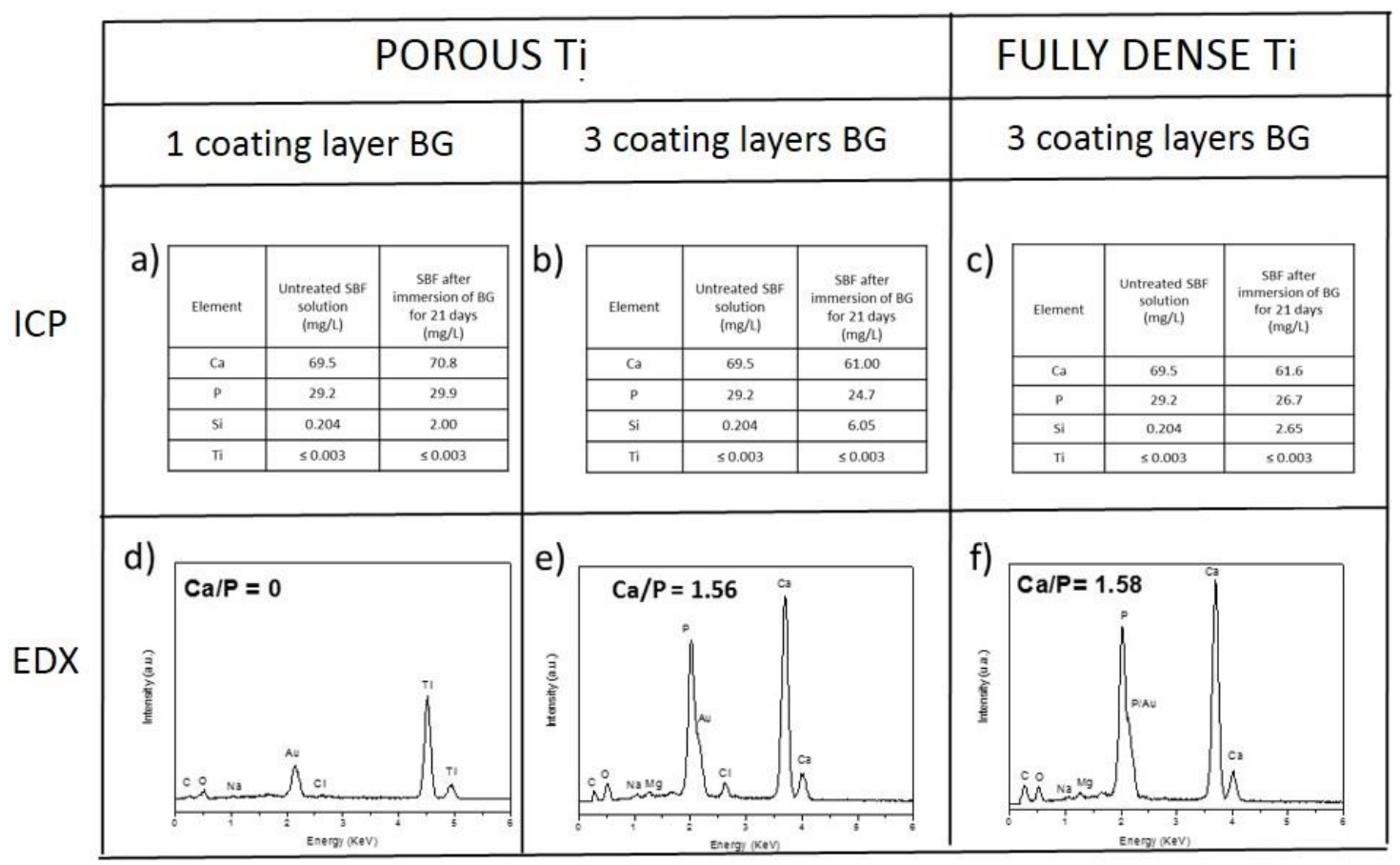

Figure 9 